\title{
Impact of $R$ and $D$ Intensity, Patents and Regulatory Filings on Export Intensity of Indian Pharmaceutical Industry
}

\author{
Amit Banerji', Feroz Suri2,* \\ ${ }^{1}$ Department of Management Studies, Maulana Azad National Institute of Technology, Bhopal, Madhya Pradesh, INDIA. \\ ${ }^{2}$ Regional Centre for Biotechnology, NCR Biotech Science Cluster, $3^{\text {rd }}$ Milestone, Faridabad-Gurugram Expressway, Faridabad, \\ Haryana, INDIA.
}

\begin{abstract}
$R$ and $D$ is necessary for growth of hi-tech sectors like pharmaceuticals and is aimed at boosting innovation. Innovation brings new products that could earn revenues to further boost R and D. Indian pharmaceutical industry earns nearly sixty percent of its revenues from exports and is a leader in global generics market with largest share of ANDA and DMF filings. Significant increase in patenting activity is also observed post India's accession to TRIPS agreement in 1995 and subsequent introduction of product patent regime in 2005. This study aims at establishing a causal relationship amongst $R$ and $D$ intensity, patents, regulatory filings and export intensity. Also, the impact of these variables on export intensity of Indian pharmaceutical sector has been studied by fitting them into an econometric model. Results of the econometric analysis suggested that the current year $R$ and $D$ intensity had a positive and significant impact on pharmaceutical export intensity and that the lagged year regulatory filings had a positive and significant impact on export intensity of Indian pharmaceutical industry. Study concluded that creation of state-of-the-art $R$ and $D$ facilities and manufacturing plants (complying with US and EU norms) was aimed at developing and exporting generic drugs to regulated markets of US and Europe and Indian pharmaceutical industry had not committed enough financial resources on developing new patented products for global markets.
\end{abstract}

Key words: Indian pharmaceutical industry, R and D intensity, Export intensity, Innovation and export intensity, Patents.

\section{INTRODUCTION}

Increase in $\mathrm{R}$ and $\mathrm{D}$ spend is in consonance with increase in pharmaceutical exports from Indian pharmaceutical sector. There has been a significant increase in $\mathrm{R}$ and $\mathrm{D}$ spend by the Indian companies post TRIPS agreement in 1995. Despite more money being spent of pharmaceutical R and D in India post signing of the TRIPS agreement; it is significantly less in comparison to the global multinationals. ${ }^{1}$ India accounts for twenty percent of global exports of pharmaceutical generics and exported generics worth USD 16.89 billion to global markets in 2016. India's pharmaceutical industry achieved a positive trade balance. ${ }^{3}$ By 2016, exports contributed nearly sixty percent revenue of Indian pharmaceutical sector and few leading companies had approximately 65 to 70 percent of their total sales contribution from exports. Indian firms have become more export oriented but also more export dependent and that growth in Indian pharmaceutical exports is key to sustainable growth of this sector.

\section{Status of Pharmaceutical R and D in India}

$\mathrm{R}$ and $\mathrm{D}$ spend of Indian Pharmaceutical companies have been increasing significantly since 2005. Due to large investments,
Submission Date: 21-03-2019; Revision Date: 24-05-2019; Accepted Date: 04-09-2019

DOI: 10.5530/ijper.53.4.125 Correspondence: Dr. Feroz Suri,

CEO-Office of Connectivity, Regional Centre for Biotechnology, NCR Biotech Science Cluster,

3rd Milestone, FaridabadGurugram Expressway, Faridabad, Haryana121001, INDIA. Phone: +91-0129 2848535 E-mail: ferozkhansuri@ gmail.com

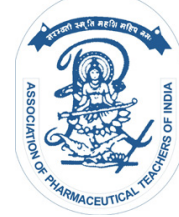

www.ijper.org 


\begin{tabular}{|c|c|}
\hline $\begin{array}{c}\text { Table 1: Percentages of Global ANDA Filings by } \\
\text { Indian Companies. }{ }^{13}\end{array}$ \\
\hline Year & $\begin{array}{c}\text { Percentage of Global ANDA Filings by } \\
\text { Indian companies }\end{array}$ \\
\hline 2009 & $45 \%$ \\
\hline 2010 & $49 \%$ \\
\hline 2011 & $51 \%$ \\
\hline 2012 & $37 \%$ \\
\hline 2013 & $44 \%$ \\
\hline 2014 & $40 \%$ \\
\hline 2015 & $40 \%$ \\
\hline
\end{tabular}

Source: USFDA, 2015

companies have built strong product pipelines for the US market but negligible development on the NCE front. ${ }^{4}$ Majority of Indian Pharmaceutical companies have been focusing on developing strong Abbreviated New Drug Applications (ANDA) pipelines and due to the majority effort and investment is going on ANDAs, India's share in overall ANDA filings have been ever increasing as shown in Table 1.

Indian generics were benefitting from the wave of patent expiries and it is expected to continue in the midterm as branded products worth approximately USD 100 billion would be off patent by 2020. Almost all leading Indian companies have been expanding their ANDA pipelines in line with the patent expiries. Over the years, Indian companies have been increasing their share of First to File ANDAs (FTFs) and Paragraph IV filings so that they get six months exclusive marketing rights in the US market. $\mathrm{R}$ and $\mathrm{D}$ efforts were increasingly focused on building exclusivities through FTFs/Para IV filings as plain generics were becoming highly competitive leaving narrow margins to the companies. ${ }^{5}$

Figure 1 shows the trend of increasing $\mathrm{R}$ and $\mathrm{D}$ expenditure from Indian pharmaceutical industry and by 2015-16, the sector spent $7.8 \%$ of net sales on research and

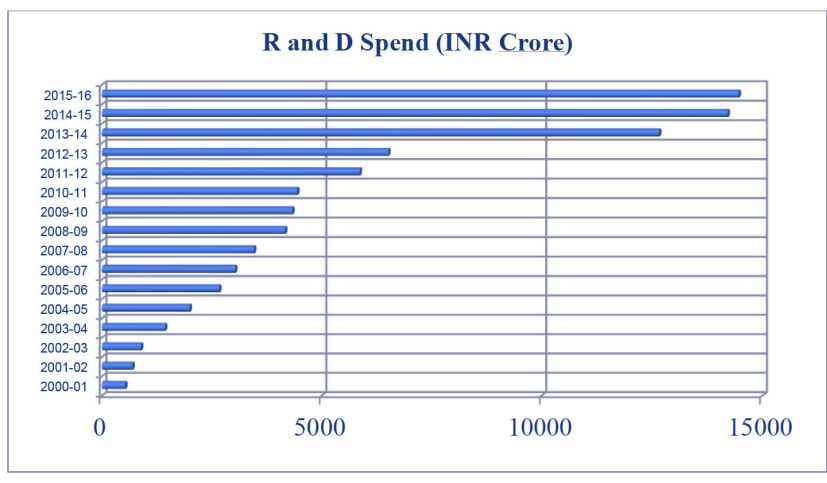

Figure 1: R and D Spend of Indian Pharmaceutical Industry. Source: Center for Monitoring of Indian Economy, 2016

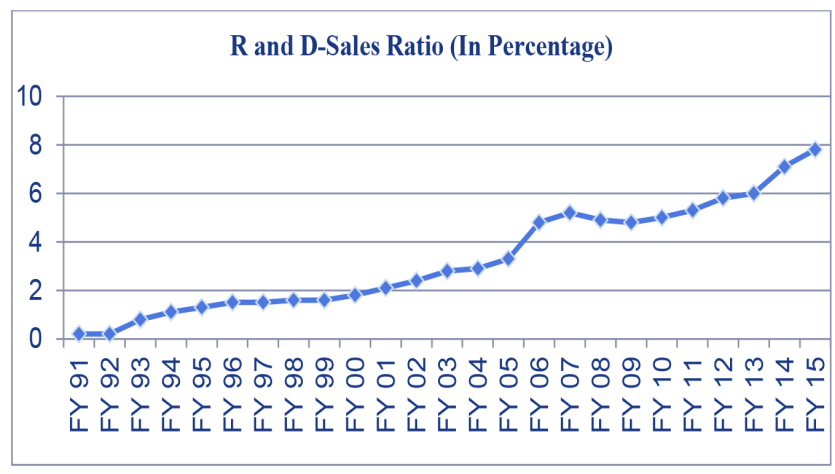

Figure 2: $\mathbf{R}$ and $\mathbf{D}$ to Sales Ratio (In Percentage).

Source: Centre for Monitoring of Indian Economy, 2016

development. $\mathrm{R}$ and $\mathrm{D}$ to sales ratio had grown steadily since $1^{\text {st }}$ January 2005 due to introduction of product patent regime in India and Indian pharmaceutical sector spent on an average $7.8 \%$ of net sales on $\mathrm{R}$ and $\mathrm{D}$ as compared to $2 \%$ in 2000 as shown in Figure 2. There has been a significant increase in R and D spend by the Indian companies post TRIPS agreement in 1995. Despite more money being spent of pharmaceutical $\mathrm{R}$ and $\mathrm{D}$ in India post signing of the TRIPS agreement; it is significantly less in comparison to the global MNCs. ${ }^{6}$ Pingle, 2016 reported that Sun Pharmaceuticals had highest R and D expenditure during 2015-16 followed by Dr. Reddy's Laboratories, Lupin Pharmaceuticals, Cipla and Cadila.

$\mathrm{R}$ and $\mathrm{D}$ to sales ratio of Indian pharmaceutical industry has been ever increasing with approximately 6 to $7 \%$ of sales being utilized for $\mathrm{R}$ and $\mathrm{D}$. $^{7}$ Indian pharmaceutical industry leveraged its strength in reverse engineering and manufacturing of generic drugs for the developed markets like US and Europe. Almost all big players have been developing niche products with some exclusivity to sustain sales and profits but eventually Indian Pharma Industry has to move up in the drug development value chain to develop skills, expertise and create funding opportunities to develop and commercialize NCEs. ${ }^{8}$

Increase in number of product patent filing by Indian companies in the product patent regime post 2005 has been observed. Majority of the applications were related to new and improved processes for products than for novel products. Product related applications were concerned with incremental work on formulations with modified release systems and novel drug delivery systems. ${ }^{6}$ Most of the patenting activity by Indian Pharmaceutical companies had been revolving around incremental research and majority budget is being spent on reverse engineering to expand ANDA, FTF/Para IV pipeline. 


\section{Patenting Activity of Indian Pharmaceutical Industry}

Patenting innovations is an important parameter of measuring the output of $\mathrm{R}$ and $\mathrm{D}$ activity of the Indian Pharmaceutical Industry. Inventions are patented in respective countries through conventional route or simultaneously in multiple countries through Patent Co-operation Treaty (PCT). Inventions relating to processes or products are eligible for grant of a patent. Nowadays, several patents are granted wherein formulations developed are protected by claiming every indication/use of the drug product.'

The patent filing data shows an upward trend during the period 1997-2006 and displaying a significant rise around 2005 when India introduced the product patent regime as shown in Table 2. However, post the initial spike in filing, the patent filing trend has stabilized in the last 3-4 years and a growth though predicted, is not expected to be large but steady in nature. ${ }^{10}$

World Intellectual Property Organization (WIPO) statistics for pharmaceutical patents granted globally between 2000 and 2014 is shown in Table 3. Table 3 shows the number of pharmaceutical patents granted to Indian pharmaceutical firms during the same period. It can be noted that the share of Indian pharmaceutical firms remained consistently near 1 percent mark indicating a negligible presence in the global innovative space. ${ }^{11}$

WIPO statistics for PCT publications for pharmaceuticals for the period 2000 to 2014 is shown in Table 4. Table 4 shows the global PCT publications for pharmaceuticals as well as pharmaceutical PCT publications of Indian origin. It is interesting to note that India's share in global PCT publications is significantly higher as compared to the share in global patents granted.

\section{Regulatory Filings from Indian Pharmaceutical Industry}

Regulatory requirements of various countries are considerably different from each other. It is challenging for pharmaceutical firms to develop a single drug that meets the regulatory requirements of all countries. Regulatory authorities not only specify the quality, safety and efficacy of a drug product but also prescribe the

\begin{tabular}{|c|c|c|}
\hline \multicolumn{3}{|c|}{ Table 2: Pharmaceutical Patent Applications Filed at } \\
Indian Patent Office (IPO). ${ }^{10}$
\end{tabular}

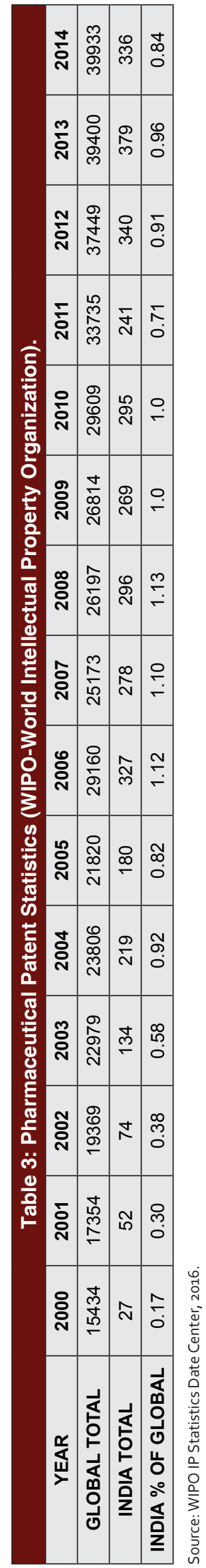

Source: Gokhale and Kannan (2012). 


\begin{tabular}{|c|c|c|c|c|c|c|c|c|c|c|c|c|c|c|c|}
\hline YEAR & 2000 & 2001 & 2002 & 2003 & 2004 & 2005 & 2006 & 2007 & 2008 & 2009 & 2010 & 2011 & 2012 & 2013 & 2014 \\
\hline PCTs GLOBAL & 3808 & 4356 & 4864 & 5586 & 5845 & 7476 & 8677 & 8795 & 8960 & 8400 & 7837 & 7715 & 7814 & 7739 & 8590 \\
\hline PCTs FROM INDIA & 29 & 47 & 73 & 112 & 160 & 202 & 223 & 235 & 224 & 228 & 250 & 255 & 295 & 256 & 285 \\
\hline INDIA \% OF GLOBAL & $0.8 \%$ & $1.1 \%$ & $1.5 \%$ & $2.0 \%$ & $2.7 \%$ & $2.7 \%$ & $2.6 \%$ & $2.7 \%$ & $2.5 \%$ & $2.7 \%$ & $3.2 \%$ & $3.3 \%$ & $3.8 \%$ & $3.3 \%$ & $3.3 \%$ \\
\hline
\end{tabular}

Source: WIPO IP Statistics Date Center, 2016.

norms for its development, manufacturing, distribution and promotion. More than 100 countries have established regulatory requirements for approval of a drug product. For a worldwide regulatory dossier submission; the company must have a thorough knowledge of country specific guidelines and norms that are to be followed while developing, manufacturing, testing, distributing and promoting a drug product. Global pharmaceutical market is divided into two groups: Regulated and Emerging Markets. Regulated markets comprises of countries having defined regulatory requirements set by regulatory authorities. North America (including US and Canada) and European Union are the biggest and are categorized as regulated markets. Emerging markets are those countries that are still in the process of putting forward a defined set of regulations for drugs. These include Rest of the World (ROW) with Brazil, Russia, India, China and South Africa being the largest and high potential emerging markets. ${ }^{12}$

Regulatory filings are further divided into two groups namely; bulk drugs and formulations. Regulatory filing or the dossier required to be filed for bulk drug is called DMF (Drug Master File). DMF is to be filed before the USFDA for authorizing the use of a bulk drug in a formulation that is intended to be sold in the US market. In US, regulatory filing with USFDA to obtain marketing authorization for a formulation (new product) is called NDA (New Drug Application) and for a generic product is called ANDA (Abbreviated New Drug Application). ${ }^{13}$ In Europe, regulatory filing with EMA (European Medicines Agency) for a formulation is called Marketing Authorization.

India's Pharmaceutical Industry is known "Global pharmacy of the world". India offers almost every product which has gone off patent and with a large base of manufacturing units. During the period 2008-2017, US FDA approved total 5,020 ANDAs and 1184 tentative approvals. Out of this, Indian companies achieved 1,695 ANDA approvals and 455 tentative approvals. ${ }^{14}$ The average rate of securing approvals by Indian pharma companies worked out to almost 34 per cent for last decade (2008-2017). Thus, Indian pharma companies received healthy product approvals from highly regulated
US body which turned into higher export earnings. ${ }^{15}$ Many prior studies have been done to analyze the innovative activities of Indian pharmaceutical industry post TRIPS and post introduction of product patent regime. Majority of these studies analyzed the trend of $\mathrm{R}$ and $\mathrm{D}$ expenditure and patenting activity post TRIPS and few of them studied the relationship of $\mathrm{R}$ and $\mathrm{D}$ activity and exports. ${ }^{15,19-21}$ This study is unique in terms of analyzing the impact of $\mathrm{R}$ and $\mathrm{D}$ intensity, regulatory filings and patents on export intensity of Indian pharmaceutical industry because Indian pharmaceutical sector is largely export oriented and major export revenue is from supply of generics to highly regulated markets like North America, Europe, South Africa, Russia and Latin America.

There have been many studies that discussed the effect of $\mathrm{R}$ and $\mathrm{D}$ intensities on firm productivity, profitability and export performance in technology intensive sectors like pharmaceuticals, electronics, information technology and automobiles. It was observed that $\mathrm{R}$ and $\mathrm{D}$ activities had a greater role on growth, sustainability, profitability and export performance in drugs, chemicals and pharmaceutical sector. Post 2005, Indian pharmaceutical sector had seen a significant increase in $\mathrm{R}$ and $\mathrm{D}$ intensity. During the same period; the Indian pharmaceutical sector had also shown a significant increase in exports ${ }^{16-18}$ It is therefore important to assess the impact of increasing $\mathrm{R}$ and $\mathrm{D}$ intensity, regulatory filings (ANDAs and DMFs) and total patents granted on the export intensity of Indian pharmaceutical sector. This study aims at analyzing the impact of $\mathrm{R}$ and $\mathrm{D}$ intensity, regulatory filings and total patents granted on export intensity of Indian pharmaceutical industry by fitting the variables in a structural model. Here export intensity has been taken as dependent variable and $\mathrm{R}$ and $\mathrm{D}$ intensity, regulatory filings and total patents granted as independent variables. On the basis of interpretations made from the literature review and gaps identified for this study; following hypothesis was framed:

\section{Hypothesis}

- $\mathrm{H}_{1}-\mathrm{R}$ and $\mathrm{D}$ intensity affects exports intensity

- $\mathrm{H}_{2}-$ Exports intensity affects $\mathrm{R}$ and $\mathrm{D}$ intensity 
- $\mathrm{H}_{3}-\mathrm{R}$ and $\mathrm{D}$ intensity affects Regulatory filings

- $\mathrm{H}_{4}-\mathrm{R}$ and $\mathrm{D}$ intensity affects total patent grants

\section{Data, Methodology and Analysis}

The study uses real financial data for Indian pharmaceutical industry for period 2000-01 to 2013-14. The study period starts from 2000-01 as the R and D intensity of Indian pharmaceutical industry; patent data as well as regulatory filings were negligible prior to 2000-01. As the study takes into the regulatory filings, therefore the data up to 2013-14 has been taken into account as USFDA was reporting ANDA and DMF filings till 2013-14 and thereafter the reporting pattern changed to ANDA and DMF approvals. For this reason, the study period was selected as 2000-01 to 2013-14. The data for exports and $\mathrm{R}$ and $\mathrm{D}$ expenditure have been drawn from Center for Monitoring of Indian Economy (CMIE), Prowess Database. Data for ANDA and DMF filings (referred as regulatory filings) have been taken from annual reports of Department of Pharmaceuticals, Government of India and United States Food and Drug Administration (USFDA). Patent data has been extracted from World Intellectual Property Organization (WIPO) Statistics Database. Table 5 shows the data set on regulatory filings and patents for the study period and Table 6 enumerates data on total sales, exports, $\mathrm{R}$ and $\mathrm{D}$ expenditure, Export intensity and $\mathrm{R}$ and $\mathrm{D}$ intensity of Indian Pharmaceutical Industry.

\section{Methodology}

Eviews 8 was used for statistical and econometric analysis. All data points were made stationary by converting to natural $\log$ and then taking first difference. A stationary time series is the one whose mean, variance and auto correlation structure is constant over time. Stationarity is important in time series analysis as two random variables can be independent in one way, but they can be dependent in various ways. So, stationarity is a way of modeling the dependent structure. Therefore, the concept of stationarity is important for modeling non-independent data. In addition to this, stationary processes avoid the problem of spurious regression. Data transformation was performed to achieve stationarity. If the time series is non-stationary, it can be transformed with differencing the data. The differenced data will have one less point than the original data. Differencing can be done more than once. However, one difference is usually sufficient. For non-constant variance, taking the logarithm of the series stabilized the variance.

This study attempts at determining a causal relationship between variables namely; $\mathrm{R}$ and $\mathrm{D}$ intensity (RDI), pharmaceutical export intensity (PEI), regulatory filings (RF) and total patents granted (TP). Econometric analysis was performed using Granger causality to test two way causal relationships amongst the variables. This was followed by fitting the variables into Autoregressive distributed lag (ARDL) model.

Granger causality is a way to investigate causality between two variables in a time series. The method is a probabilistic account of causality. It uses empirical data sets to find patterns of correlation. Granger causality is used to understand the causal effects amongst variables. It is a statistical concept of causality that is based on prediction. According to Granger causality, if a signal $\mathrm{X} 1$ "Granger-causes" a signal X2, then past values of $\mathrm{X} 1$ should contain information that helps predict X2 above and beyond the information contained in past values of X2 alone. Its mathematical formulation is based on linear regression modeling of stochastic processes. ${ }^{22}$ In applied econometrics, the Granger (1981) and Engle and Granger (1987), Auto-regressive Distributed Lag (ARDL) technique have become the solution to determining the long run relationship between series that are non stationary. Autoregressive distributed lag (ARDL) are standard least squares regressions which include lags of both dependent variable and explanatory variables as regressors. ${ }^{23}$ ARDL models have been in use for decades but they gained popularity in recent years as a method of examining long-run relationships between variables. ARDL technique is used when dealing with variables in a small sample size as in this case only 13 relevant data points are available. ARDL model is used to analyze relationship between variables namely; $\mathrm{R}$ and $\mathrm{D}$ intensity, regulatory filings, total patents and pharmaceutical exports intensity, especially with lagged values.

Pairwise Granger causality test with two years amongst variables namely; pharmaceutical export intensity and $\mathrm{R}$ and $\mathrm{D}$ intensity suggested that pharmaceutical export intensity Granger Causes R and D intensity. Also, regulatory filings were found to be Granger Causing R and $\mathrm{D}$ intensity. Total patents granted to the Indian pharmaceutical industry were found to be Granger causing $\mathrm{R}$ and $\mathrm{D}$ intensity and regulatory filings were found to be Granger causing total patents (Table 7).

Results of Pairwise Granger causality test with one year lag (as shown in Table 8) are more significant as compared to that with two years lag. R and $\mathrm{D}$ intensity was found to be Granger causing export intensity. Regulatory filings were found to be Granger causing $\mathrm{R}$ and $\mathrm{D}$ intensity. Regulatory filings as well as total patents were also found to be Granger causing pharmaceutical exports. Also, two way Granger causality was found between total patents and regulatory filings. 


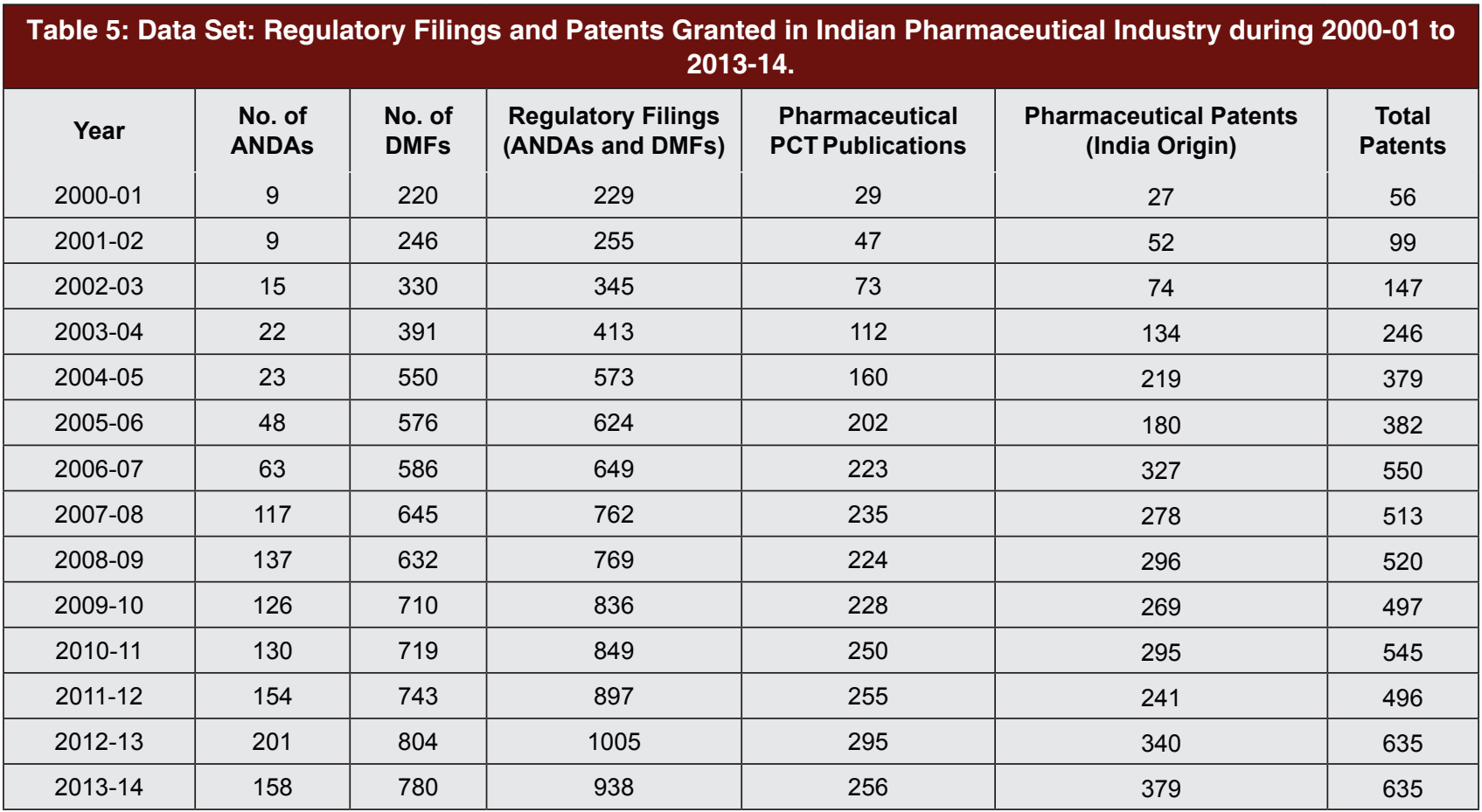

Source; Annual reports of Department of Pharmaceuticals-Government of India, WIPO IP Statistics Data Center.

\begin{tabular}{|c|c|c|c|c|c|}
\hline \multicolumn{2}{c}{$\begin{array}{c}\text { Table 6: Data Set: Total Sales, Exports, R and D Expenditure, Export Intensity and } \\
\text { R and D Intensity of Indian Pharmaceutical Indian Industry during 2000-01 to 2013-14. }\end{array}$} \\
\hline Year & $\begin{array}{c}\text { Pharma Sales } \\
\text { (INR Crores) }\end{array}$ & $\begin{array}{c}\text { Pharma Exports } \\
\text { (INR Crores) }\end{array}$ & $\begin{array}{c}\text { R and D } \\
\text { Expenditure (INR } \\
\text { Crores) }\end{array}$ & $\begin{array}{c}\text { Pharma Export } \\
\text { Intensity }\end{array}$ & $\begin{array}{c}\text { Pharma R and D } \\
\text { Intensity }\end{array}$ \\
\hline $2000-01$ & 26391 & 10557 & 526 & 0.400023 & 0.019931 \\
\hline $2001-02$ & 28581 & 13643 & 691 & 0.477345 & 0.024177 \\
\hline $2002-03$ & 32772 & 12826 & 887 & 0.391371 & 0.027066 \\
\hline $2003-04$ & 39859 & 15213 & 1433 & 0.38167 & 0.035952 \\
\hline $2004-05$ & 42942 & 17228 & 1993 & 0.401192 & 0.046411 \\
\hline $2005-06$ & 52535 & 21230 & 2663 & 0.404112 & 0.05069 \\
\hline $2006-07$ & 63573 & 25666 & 3027 & 0.403725 & 0.047615 \\
\hline $2007-08$ & 73597 & 29354 & 3455 & 0.398848 & 0.046945 \\
\hline $2008-09$ & 85298 & 39821 & 4161 & 0.466846 & 0.048782 \\
\hline $2009-10$ & 97419 & 42456 & 4328 & 0.435808 & 0.044427 \\
\hline $2010-11$ & 110977 & 48810 & 4438 & 0.439821 & 0.03999 \\
\hline $2011-12$ & 123096 & 65000 & 5859 & 0.528043 & 0.047597 \\
\hline $2012-13$ & 121506 & 79400 & 6509 & 0.653466 & 0.053569 \\
\hline $2013-14$ & 136949 & 81234 & 6659 & 0.593169 & 0.048624 \\
\hline
\end{tabular}

Source: CMIE, Prowess Database and Directorate General of Commercial Statistics and Intelligence, Govt. of India.

Once the Granger causality was tested; the variables were fitted in Autoregressive distributed Lag (ARDL) model. Pharmaceutical exports intensity was kept as dependent variable whereas $\mathrm{R}$ and $\mathrm{D}$ intensity, total patents and regulatory filings were kept as independent variables. Results of the ARDL model using ordinary least squares method (OLS method) is provided in Table 9.

Estimation equation suggested that the current year $\mathrm{R}$ and $\mathrm{D}$ intensity is having a strong and significant impact on pharmaceutical export intensity. Lagged year regulatory filings were found to have a significant and 


\begin{tabular}{|c|c|c|c|}
\hline \multicolumn{4}{|c|}{ Pairwise Granger Causality Tests } \\
\hline \multicolumn{3}{|c|}{ Sample: 114} & \multirow[b]{3}{*}{ Prob. } \\
\hline \multicolumn{2}{|l|}{ Lags: 2} & \multirow[b]{2}{*}{ F-Statistic } & \\
\hline Null Hypothesis: & Obs & & \\
\hline $\begin{array}{c}\text { DRDI does not Granger Cause } \\
\text { DPEI }\end{array}$ & 11 & 1.99805 & 0.2163 \\
\hline \multicolumn{2}{|c|}{ DPEI does not Granger Cause DRDI } & 7.82871 & 0.0213 \\
\hline $\begin{array}{c}\text { DRF does not Granger Cause } \\
\text { DPEI }\end{array}$ & 11 & 2.11955 & 0.2012 \\
\hline \multicolumn{2}{|c|}{ DPEI does not Granger Cause DRF } & 2.25267 & 0.1863 \\
\hline $\begin{array}{c}\text { DTP does not Granger Cause } \\
\text { DPEI }\end{array}$ & 11 & 1.96937 & 0.2200 \\
\hline \multicolumn{2}{|c|}{ DPEI does not Granger Cause DTP } & 2.66938 & 0.1482 \\
\hline $\begin{array}{c}\text { DRF does not Granger Cause } \\
\text { DRDI }\end{array}$ & 11 & 6.39414 & 0.0326 \\
\hline \multicolumn{2}{|c|}{ DRDI does not Granger Cause DRF } & 4.16099 & 0.0735 \\
\hline $\begin{array}{c}\text { DTP does not Granger Cause } \\
\text { DRDI }\end{array}$ & 11 & 6.88728 & 0.0279 \\
\hline \multicolumn{2}{|c|}{ DRDI does not Granger Cause DTP } & 26.8067 & 0.0010 \\
\hline $\begin{array}{c}\text { DTP does not Granger Cause } \\
\text { DRF }\end{array}$ & 11 & 1.96293 & 0.2209 \\
\hline \multicolumn{2}{|c|}{ DRF does not Granger Cause DTP } & 13.0197 & 0.0066 \\
\hline
\end{tabular}

\begin{tabular}{|c|c|c|c|}
\hline \multicolumn{4}{|c|}{$\begin{array}{l}\text { Table 8: Pairwise Granger Causality } \\
\text { (with 1-year lag). }\end{array}$} \\
\hline \multicolumn{4}{|c|}{ Pairwise Granger Causality Tests } \\
\hline \multicolumn{3}{|c|}{ Sample: 114} & \\
\hline \multicolumn{2}{|l|}{ Lags: 1} & & \\
\hline Null Hypothesis: & Obs & F-Statistic & Prob. \\
\hline $\begin{array}{c}\text { DPEI does not Granger Cause } \\
\text { DRDI }\end{array}$ & 12 & 0.60300 & 0.4574 \\
\hline \multicolumn{2}{|c|}{ DRDI does not Granger Cause DPEI } & 3.75138 & 0.0847 \\
\hline $\begin{array}{c}\text { DRF does not Granger Cause } \\
\text { DRDI }\end{array}$ & 12 & 20.0445 & 0.0015 \\
\hline \multicolumn{2}{|c|}{ DRDI does not Granger Cause DRF } & 78.3758 & 1.E-05 \\
\hline $\begin{array}{c}\text { DTP does not Granger Cause } \\
\text { DRDI }\end{array}$ & 12 & 64.8069 & 2.E-05 \\
\hline \multicolumn{2}{|c|}{ DRDI does not Granger Cause DTP } & 469.740 & 4.E-09 \\
\hline $\begin{array}{c}\text { DRF does not Granger Cause } \\
\text { DPEI }\end{array}$ & 12 & 3.89655 & 0.0798 \\
\hline \multicolumn{2}{|c|}{ DPEI does not Granger Cause DRF } & 0.93581 & 0.3586 \\
\hline $\begin{array}{c}\text { DTP does not Granger Cause } \\
\text { DPEI }\end{array}$ & 12 & 3.90333 & 0.0796 \\
\hline \multicolumn{2}{|c|}{ DPEI does not Granger Cause DTP } & 0.81170 & 0.3911 \\
\hline $\begin{array}{c}\text { DTP does not Granger Cause } \\
\text { DRF }\end{array}$ & 12 & 17.6064 & 0.0023 \\
\hline \multicolumn{2}{|c|}{ DRF does not Granger Cause DTP } & 12.5278 & 0.0063 \\
\hline
\end{tabular}

\begin{tabular}{|c|c|c|c|c|}
\hline \multicolumn{5}{|c|}{ Dependent Variable: PEI } \\
\hline \multicolumn{5}{|c|}{ Method: Least Squares } \\
\hline \multicolumn{5}{|c|}{ Sample (adjusted): 214} \\
\hline \multicolumn{5}{|c|}{ Included observations: 13 after adjustments } \\
\hline Variable & Coefficient & Std. Error & t-Statistic & Prob. \\
\hline RDI & 7.830368 & 2.846284 & 2.751085 & 0.0403 \\
\hline LNTP & -0.129055 & 0.097836 & -1.319097 & 0.2443 \\
\hline LNRF & 0.249905 & 0.215931 & 1.157340 & 0.2994 \\
\hline C & -1.387805 & 0.445791 & -3.113127 & 0.0265 \\
\hline PEI (-1) & 0.368086 & 0.191750 & 1.919616 & 0.1130 \\
\hline RDI (-1) & -1.265347 & 3.769674 & -0.335665 & 0.7508 \\
\hline $\operatorname{LNTP}(-1)$ & -0.297353 & 0.096082 & -3.094786 & 0.0270 \\
\hline $\operatorname{LNRF}(-1)$ & 0.356776 & 0.120209 & 2.967952 & 0.0312 \\
\hline R-squared & 0.936636 & \multicolumn{2}{|c|}{ Mean dependent var } & 0.459647 \\
\hline $\begin{array}{l}\text { Adjusted } \\
\text { R-squared }\end{array}$ & 0.847926 & \multicolumn{2}{|c|}{ S.D. dependent var } & 0.084393 \\
\hline $\begin{array}{l}\text { S.E. of } \\
\text { regression }\end{array}$ & 0.032910 & \multicolumn{2}{|c|}{ Akaike info criterion } & -3.714808 \\
\hline $\begin{array}{l}\text { Sum squared } \\
\text { resid }\end{array}$ & 0.005415 & \multicolumn{2}{|c|}{ Schwarz criterion } & -3.367147 \\
\hline Log likelihood & 32.14625 & \multicolumn{2}{|c|}{ Hannan-Quinn criter. } & -3.786268 \\
\hline F-statistic & 10.55845 & \multicolumn{2}{|c|}{ Durbin-Watson stat } & 1.579074 \\
\hline Prob(F-statistic) & 0.009784 & & & \\
\hline
\end{tabular}

positive impact on pharmaceutical export intensity. Last year total patents had a significant but negative impact on pharmaceutical export intensity. The results of ARDL model (Table 9) suggests that $1 \%$ increase in total patents granted (lagged year) leads to reduction in pharmaceutical exports intensity by 0.0029 units. Also, it was observed that $1 \%$ increase in regulatory filings (lagged year) leads to increase in pharmaceutical exports intensity by 0.0035 units. The intercept (constant) has a negative value (-1.3878). It implies that in absence of independent variables namely lagged year total patents and regulatory filings; Indian would become net importer of pharmaceutical products. The ARDL model passes normality test as the residuals were distributed normally (Figure 3). The model is able to explain 93\% variation in pharmaceutical export intensity in the sample period. It is also a highly significant model with $\mathrm{F}$-stat value of 10.56 (approx.) at 5\% significance. Durbin Watson stat value is between 1.5 and 2.5 signifying nil auto correlation.

\section{Estimation Equation:}

$\mathrm{PEI}=\mathrm{C}(1) * \mathrm{RDI}+\mathrm{C}(2) * \mathrm{LNTP}+\mathrm{C}(3) * \mathrm{LNRF}+\mathrm{C}(4)$ $+\mathrm{C}(5) * \mathrm{PEI}(-1)+\mathrm{C}(6) * \mathrm{RDI}(-1)+\mathrm{C}(7) * \mathrm{LNTP}(-1)+$ $\mathrm{C}(8) * \operatorname{LNRF}(-1)$ 


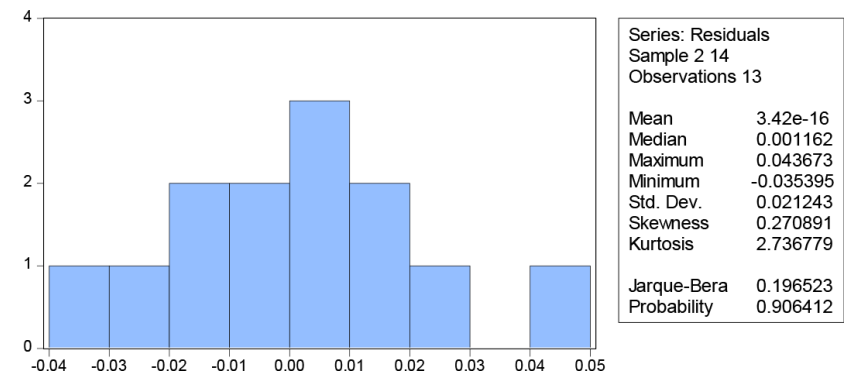

Figure 3: Residual Normality Test.

\section{$\underline{\text { Substituted Coefficients }}$}

PEI $=7.83036786817 *$ RDI $-0.129054815071 * \mathrm{LNTP}+$ $0.249905471423 * \mathrm{LNRF}-1.38780509718+0.368086$ 474034*PEI(-1)-1.26534694728*RDI $(-1)-0.2973529$ 06006*LNTP $(-1)+0.356775923807 * \operatorname{LNRF}(-1)$

\section{RESULTS AND DISCUSSION}

Pair wise Granger causality amongst variables namely; $\mathrm{R}$ and $\mathrm{D}$ intensity, total patents granted, regulatory filings and export intensity was studied to determine the causal relationship amongst these variables with one-year lag. It was found that $\mathrm{R}$ and $\mathrm{D}$ intensity Granger causes export intensity. A two-way causal relationship was found between regulatory filings and R and D intensity. Similarly, a two-way causal relationship was observed amongst variables; total patents and regulatory filings. Also, total patents granted as well as regulatory filings were found to be Granger causing pharmaceutical export intensity.

Pair wise Granger causality amongst these variables was studied using two years lag as well and it was found that pharmaceutical export intensity Granger causes R and $\mathrm{D}$ intensity. Total patents were found to be Granger causing $\mathrm{R}$ and $\mathrm{D}$ intensity and a reverse causality was also found in this case. Regulatory filings were found to be causing $\mathrm{R}$ and $\mathrm{D}$ intensity as well as total patent grants with two years lag.

Results of Granger causality tests can be explained with the fact that $\mathrm{R}$ and $\mathrm{D}$ expenditure is aimed at developing new products for domestic as well as overseas markets. These findings are in line with the recent trend amongst leading Indian pharmaceutical firms to invest in $\mathrm{R}$ and $\mathrm{D}$ to boost their presences in regulated markets like US and Europe and that the ANDA and DMF approvals are one of the major $\mathrm{R}$ and $\mathrm{D}$ productivity indicators in India. This is in line with well-established trade-innovation macroeconomic framework that offers mainstream theoretical models to account for a relationship between $\mathrm{R}$ and $\mathrm{D} /$ innovation and exporting with the causation running from the former to the latter. This theoretical model is supported by the fact that a majority of pharmaceutical exports from India is to North America and especially for products going off patent in specific years. Moreover, due to intense competition and rapid price erosion in the generic drug market of North America, Indian companies have to build a pipeline of ANDAs to retain sales. Also, due to price erosion, it becomes imperative for Indian firms to remain competitive in terms of pricing to retain their market share for respective products. This requires continuous $\mathrm{R}$ and $\mathrm{D}$ effort for process innovation to reduce costs. Furthermore, increasing exports to a certain geographical destination leads to further export orders requiring capacity expansion and process modification. Investments in Research and Development ( $\mathrm{R}$ and $\mathrm{D})$ by Indian pharma companies had helped the Indian pharmaceutical sector to establish strong presence in the highly regulated markets (North America and Europe) as well as in emerging markets (Brazil, Russia, South Africa and China). India has a market share of $42 \%$ in the generic medicine market of Africa and Middle East taken together. Indian companies have filed the highest number of DMFs with USFDA in 2016 and the total number of ANDAs filed from India till June 2017 was 4000. Indian pharmaceutical industry therefore became global pharmacy for the world as it offered almost every pharmaceutical product patent expiration. ${ }^{24}$ Strong competition in international market and patent expiration motivated Indian companies to step up $\mathrm{R}$ and $\mathrm{D}$ expenditure to ensure steady growth in sales. With higher investment in $\mathrm{R}$ and $\mathrm{D}$, Indian companies obtained larger share of approvals from highly regulated authorities and introduced several generic products in international market. These companies are focusing on high-barrier-to-entry products that are difficult to formulate, difficult to manufacture or may face complex legal and regulatory challenges. During 2006 to 2012, drugs worth USD 192 billion lost patent protection worldwide and Indian firms capitalized on this opportunity through development and launch of generic versions of patented products. Also, during 2013 to 2018, drugs worth USD 221 billion were to lose patent protection and Indian firms developed generic versions that could be launched upon patent expiries. ${ }^{25}$ Therefore, the result of Granger causality corroborate with the Industry trend of $\mathrm{R}$ and $\mathrm{D}$ expenditure being aimed at developing a pipeline of ANDAs and DMFs. The variables namely; pharmaceutical export intensity, $\mathrm{R}$ and $\mathrm{D}$ intensity, regulatory filings and total patent granted were fitted into an econometric model to understand the relationship amongst these variables and to derive a structural equation. For this purpose, ARDL model was used. ARDL model with ordinary least 
squares (OLS) method. Pharmaceutical export intensity was kept as dependent variable and $\mathrm{R}$ and $\mathrm{D}$ intensity, regulatory filings and total patents as independent variables. ARDL model suggested that the current year $\mathrm{R}$ and $\mathrm{D}$ intensity had a positive and significant impact on pharmaceutical export intensity. Also, the lagged year regulatory filings had a positive and significant impact on export intensity of Indian pharmaceutical industry. Results of the ARDL model suggested that lagged year total patents granted to Indian pharmaceutical industry had a significant but negative impact on export intensity. This seems to be merely a statistical artifact as patents filed through PCT route are aimed at securing innovations in overseas markets and shall have a positive impact on export intensity. This result does not corroborate with the finding of previous studies wherein patenting activity is positively affecting pharmaceutical exports. ${ }^{18}$ Total patents granted may not have a positive impact on exports over one year lag as patents are mainly a protection for an innovative product or process. It is then followed by further development and testing of the new product which may take 3-4 years time till it is approved by regulatory authorities for launch. ${ }^{26}$

\section{CONCLUSION}

Indian pharmaceutical industry had grown at a steady rate since India's compliance to TRIPS in 1995 and thereafter the introduction of product patent regime in 2005. It was observed that Indian firms increased their $\mathrm{R}$ and D expenditure significantly from 2005 mainly for two reasons namely; development of new drugs and development of generics for regulated markets of US and Europe. During the period 2005-06 to 2015-16; Indian pharmaceutical industry became more export oriented with nearly sixty percent revenue contribution from exports. Increased $\mathrm{R}$ and $\mathrm{D}$ expenditure from Indian firms lead to emergence of functional areas like $\mathrm{R}$ and $\mathrm{D}$ project management, in/out licensing and business development, that were aimed at maximizing $\mathrm{R}$ and $\mathrm{D}$ output and enhancing global outreach through various collaborative models. Indian pharmaceutical industries started investing $5-6 \%$ of their revenues into $\mathrm{R}$ and $\mathrm{D}$. However innovative output in terms of new drugs was almost negligible. Only few companies like Ranbaxy (Now Sun Pharmaceuticals), Lupin, Dr. Reddy's laboratories and Zydus Cadila were able to develop and commercialize new drugs. Most companies focused their R and D efforts towards development of super generics, first to file (FTF) applications and Paragraph IV applications for generic exclusivity in the US markets and largely towards creating a generic drugs pipeline in line with the patent expiration in US, Canada and European markets.

It was observed that creation of state-of-the-art $\mathrm{R}$ and $\mathrm{D}$ facilities and manufacturing plants (complying with US and EU norms) was aimed at developing and exporting generic drugs to regulated markets of US and Europe. Due to the changing dynamics of Indian pharmaceutical industry, $\mathrm{R}$ and $\mathrm{D}$ became the driver of exports because marketing authorizations in overseas markets (for example ANDAs in US) could be obtained with detailed product development data, quality data, good manufacturing practices (GMP) compliance, bioequivalence data and all $\mathrm{R}$ and $\mathrm{D}$ inputs. It was found from the current study that Indian pharmaceutical exports were mainly driven by regulatory filings (ANDAs and DMFs) and not by total patents granted. It is implied that in post TRIPS era (post 1995) and after the start of product patent regime (post $1^{\text {st }}$ Jan 2005); Indian pharmaceutical firms increased their $\mathrm{R}$ and $\mathrm{D}$ expenditure in order to enhance patenting activity and at the same time leveraged the opportunity of supplying generics to lucrative regulated markets like US and Europe. During the study period 2000-01 to 2013-14; there was a surge in patenting activity as well as in filing ANDAs and DMFs. In 2013, Indian firms contributed $36 \%$ of all ANDA approvals which led to approximately $40 \%$ share of Indian firms in the US generic market. It was observed that the share of exports of patented products in Indian pharmaceutical exports was very small. However, the share of Indian firms in global PCT publications in pharmaceutical domain was $3.3 \%$ which was found to be comparatively higher to the share of global patents granted. This suggests that Indian firms had been targeting overseas markets more intensively for patented products besides being amongst major generics supplier to the global markets. However, the success rate in exporting patented products to global markets had been very low. Also, the impact of total patents granted on pharmaceutical exports was comparatively weaker than that of regulatory filings especially in terms of DMFs and ANDAs. It is mainly because patents are filed during development stages of a product whereas regulatory filings are the final dossiers being filed with regulatory authorities to obtain marketing authorization in a particular geographic location/country. Moreover, regulatory filings are made with a sole purpose of exporting the product to a specific country. On the other hand, patents are filed to protect the novelty of a product. Many times the patents granted are for processes and is aimed at gaining competitive advantage and are not mainly aimed at boosting exports. Also, there are few instances wherein Indian firms have been able to get 
product patent and that the same product seldom passes regulatory scrutiny in overseas markets. There have been fewer instances of Indian firms launching an innovative patented product on global scale. ${ }^{14}$

Based on the results of the analysis of $\mathrm{R}$ and $\mathrm{D}$ expenditure, patents and regulatory filings on Pharmaceutical Exports, it was observed that $\mathrm{R}$ and $\mathrm{D}$ efforts as well as $\mathrm{R}$ and $\mathrm{D}$ expenditure made by Indian pharmaceutical industry were focused at developing generics (due to patent expiries) for developed markets especially US and Europe. It is evident that fewer resources were committed towards innovative research resulting in fewer patents. It was observed that the $\mathrm{R}$ and $\mathrm{D}$ effort of Indian pharmaceutical industry was mainly aimed at boosting exports of generics to developed markets of US and Europe where better prices and profits can be achieved. This finding was validated from the fact that nearly sixty percent of the revenue of Indian pharmaceutical firms is from exports and India has the largest share in generics market in the US. Till such time there is no structural breakthrough, the strategy of generic dominance can be pursued strongly.

\section{ACKNOWLEDGEMENT}

This research was supported by the Maulana Azad National Institute of Technology-Bhopal in terms of providing the research infrastructure required for this study. We are thankful to our colleagues from academia and industry for providing important insights to conceptualize this study. We are also grateful to Dr. Surajeet Bhattacharya (IIT-Bombay) and Dr. Ruchi Sharma (IIT-Indore) for inspiring us to analyze the impact of $\mathrm{R}$ and $\mathrm{D}$ intensity on Exports intensity of Indian Pharmaceutical Industry and we thank them for sharing their pearls of wisdom with us during the course of this research. We are also immensely grateful to Dr. Varsha Rokade and Dr. Sujoy Das for their comments on an earlier versions of the manuscript.

\section{CONFLICT OF INTEREST}

The authors whose names are listed immediately below certify that they have NO affiliations with or involvement in any organization or entity with any financial interest (such as honoraria; educational grants; participation in speakers' bureaus; membership, employment, consultancies, stock ownership, or other equity interest; and expert testimony or patent-licensing arrangements), or non-financial interest (such as personal or professional relationships, affiliations, knowledge or beliefs) in the subject matter or materials discussed in this manuscript. Amit Banerji and Feroz Khan Suri.

\section{ABBREVIATIONS}

ANDA: Abbreviated New Drug Application; ARDL: Autoregressive distributed lag; CMIE: Center for Monitoring of Indian Economy; DMF: Drug Master File; ECM: Error Correction Model; FTF: First to File; GMP: Good Manufacturing Practices; INR: Indian National Rupee; MNC: Multinational Companies; OLS: Ordinary Least Squares; PCT: Patent Cooperation Treaty; TRIPS: Patent Cooperation Treaty; USFDA: United States Food and Drug Administration.

\section{REFERENCES}

1. Reji KJ. The R and D Scenario in Pharmaceutical Industry. Research and Information Systems for Developing Countries. 2011.

2. Indian Brand Equity Foundation. Sector Report-Indian Pharmaceuticals. 2017. Available from https://guides. library.uq.edu.au/referencing/apa6/report.

3. Pharmaceutical Exports Promotion Council of India (Pharmexcil). Ministry of Commerce and Industry. Government of India. 2016.

4. India Ratings and Research. Outlook. Indian Pharmaceuticals. 2013.

5. Indian Pharmaceutical Sector. ICRA Research. 2012.

6. Bedi N, Bedi PMS. Patenting and R and D in Indian Pharmaceutical Industry: Post-TRIPS Scenario. Journal of Intellectual Property Rights. 2013;18(3):105-10.

7. Tyagi S, Nauriyal DK, Gulati R. Firm level R and D intensity: Evidence from Indian drugs and pharmaceutical industry. Review of Managerial Science. 2017. DOI 10.1007/s11846-016-0218-8.

8. Kale D, Little S. From Imitation to Innovation: The Evolution of $R$ and $D$ Capabilities and Learning Processes in the Indian Pharmaceutical Industry. Technology Analysis and Strategic Management. 2007;19(5):589-60.

9. Dhar B, Gopalkumar KM. Effects of Product Patents on Indian Pharmaceutical Industry. 2011. Available from https://guides.library.uq.edu.au/referencing/ apa6/report.

10. Gokhale P, Kannan S. Patenting trends in Indian Pharmaceutical Industry. Annals of Library and Information Studies. 2017;64(4):260-7.

11. WIPO Statistics Database.

12. Handoo S, Arora V, Khera D, Nandi PK, Sahu SK. A comprehensive study on regulatory requirements for development and filing of generic drugs globally. International Journal of Pharmaceutical Investigation. 2012;2(3):99-105.

13. US Food and Drug Administration.

14. Pingle S. Indian Pharma companies Secure 154 ANDA Approvals from USFDA during. 2013.

15. Suri FK, Banerji A. Super Generics-First Step of Indian Pharmaceutical Industry in the Innovative Space in US Market. Journal of Health Management. 2016;18(1):161-71.

16. Exports Promotion Council of India (Pharmexcil). Ministry of Commerce and Industry, Government Westphal N. Indian Generics Manufacturers penetration of US market. Decision Resources. 2013.

17. Annual Report 2016-17, Department of Pharmaceuticals, Government of India.

18. Thomas R, Narayanan K, Kathuriya V, Tyagi S, Mahajan V, Nauriyal DK. Innovations in Indian Drug and Pharmaceutical Industry: Have they impacted exports?. Journal of Intellectual Property Rights. 2014;19(4):243-52.

19. Vaidya M, Garg S, Singh C, Mahajan MM. Changing Dimensions of Drug Patents of Indian Pharmaceutical Industry. Journal of Intellectual Property Rights. 2018;23(2-3):111-8.

20. Suri FK, Banerji A. A study of disaggregated $R$ and $D$ expenditure on Indian pharmaceutical exports. The Journal of Developing Areas. 2016;50(3):167-90.

21. Suri FK, Banerji A. Patents. R and D Expenditure, Regulatory Filings and Exports in Indian Pharmaceutical Industry. Journal of Intellectual Property Rights. 2017;22(1):136-45.

22. Granger CWJ. Investigating Causal Relations by Econometric Models and Cross-Spectral Methods. Econometrica.1969;37:424-38.

23. Greene WH. Econometric Analysis. $6^{\text {th }}$ edition. Prentice Hall. 2008. 


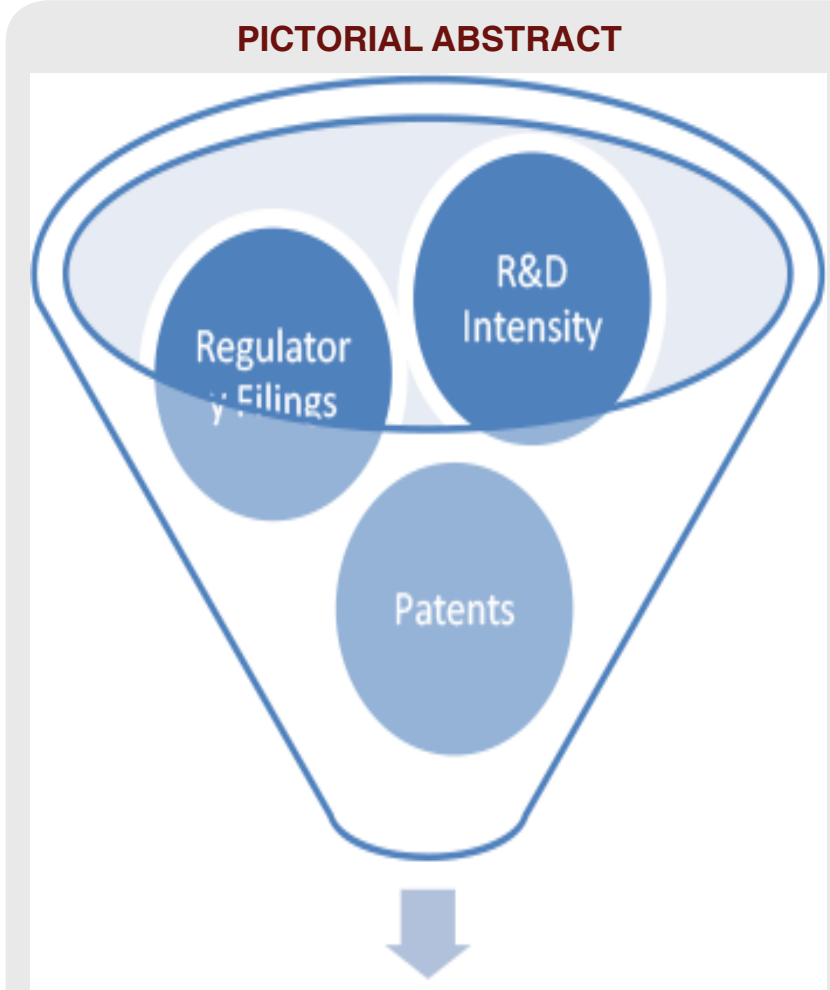

\section{Export Intensity}

Cite this article: Banerji A, Suri F. Impact of R and D Intensity, Patents and Regulatory Filings on Export Intensity of Indian Pharmaceutical Industry. Indian J of Pharmaceutical Education and Research. 2019;53(4):638-48.
It was observed that $\mathrm{R}$ and $\mathrm{D}$ activities had a greater role on growth, sustainability, profitability and export performance in drugs, chemicals and pharmaceutical sector. Post 2005, Indian pharmaceutical sector had seen a significant increase in $\mathrm{R}$ and $\mathrm{D}$ intensity. During the same period; the Indian pharmaceutical sector had also shown a significant increase in exports. Impact of $\mathrm{R}$ and $\mathrm{D}$ intensity, regulatory filings and total patents granted on export intensity of Indian pharmaceutical industry have been analyzed by fitting the variables in a structural model. Export intensity has been taken as dependent variable and $\mathrm{R}$ and $\mathrm{D}$ intensity, regulatory filings and total patents granted as independent variables. The data for exports and $\mathrm{R}$ and $\mathrm{D}$ expenditure have been drawn from Center for Monitoring of Indian Economy (CMIE), Prowess Database. Data for ANDA and DMF filings (referred as regulatory filings) have been taken from annual reports of Department of Pharmaceuticals, Government of India and United States Food and Drug Administration (USFDA). Patent data has been extracted from World Intellectual Property Organization (WIPO) Statistics Database. Two-way Granger Causality was tested amongst the variables and subsequently the variables were fitted into ARDL model. Export intensity has been taken as dependent variable and $\mathrm{R}$ and $\mathrm{D}$ intensity, regulatory filings and total patents granted as independent variables. ARDL model suggested that the current year $\mathrm{R}$ and $\mathrm{D}$ intensity had a positive and significant impact on pharmaceutical export intensity. Also, the lagged year regulatory filings had a positive and significant impact on export intensity of Indian pharmaceutical industry. It was observed that $\mathrm{R}$ and $\mathrm{D}$ efforts as well as $\mathrm{R}$ and $\mathrm{D}$ expenditure made by Indian pharmaceutical industry were focused at developing generics (due to patent expiries) for developed markets especially US and Europe. It is evident that fewer resources were committed towards innovative research resulting in fewer patents. 